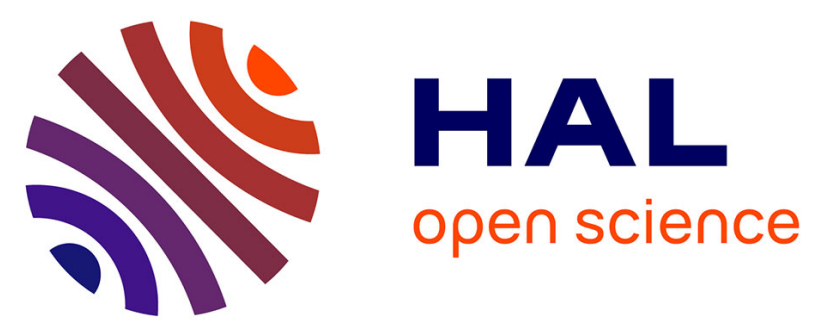

\title{
Antioxidant and Anti-inflammatory Potential of Shiitake Culinary-Medicinal Mushroom, Lentinus edodes (Agaricomycetes), Sporophores from Various Culture Conditions
}

Ibrahima Diallo, Frédéric Boudard, Sylvie Morel, Manon Vitou, Caroline Guzman, Nathalie Saint, Alain Michel, Sylvie Rapior, Lonsény Traoré, Patrick Poucheret, et al.

\section{- To cite this version:}

Ibrahima Diallo, Frédéric Boudard, Sylvie Morel, Manon Vitou, Caroline Guzman, et al.. Antioxidant and Anti-inflammatory Potential of Shiitake Culinary-Medicinal Mushroom, Lentinus edodes (Agaricomycetes), Sporophores from Various Culture Conditions. International Journal of Medicinal Mushrooms, 2020, 22 (6), pp.535-546. 10.1615/IntJMedMushrooms.2020034864 . hal-02810176

\section{HAL Id: hal-02810176 \\ https://hal.umontpellier.fr/hal-02810176}

Submitted on 6 Jun 2020

HAL is a multi-disciplinary open access archive for the deposit and dissemination of scientific research documents, whether they are published or not. The documents may come from teaching and research institutions in France or abroad, or from public or private research centers.
L'archive ouverte pluridisciplinaire HAL, est destinée au dépôt et à la diffusion de documents scientifiques de niveau recherche, publiés ou non, émanant des établissements d'enseignement et de recherche français ou étrangers, des laboratoires publics ou privés. 
Short Title: Biological Activities of Cultivated Lentinus edodes

Antioxidant and Anti-inflammatory Potential of Shiitake Culinary-Medicinal Mushroom, Lentinus edodes (Agaricomycetes) Sporophores from Various Culture Conditions

Ibrahima Diallo, ${ }^{\mathrm{a}, \mathrm{b}, \mathrm{c}}$ Fréderic Boudard, ${ }^{\mathrm{d}}$ Sylvie Morel, ${ }^{\mathrm{b}}$ Manon Vitou, ${ }^{\mathrm{b}}$ Caroline Guzman, ${ }^{\mathrm{d}}$ Nathalie Saint, ${ }^{\mathrm{e}}$ Alain Michel, ${ }^{\mathrm{a}}$ Sylvie Rapior, ${ }^{\mathrm{b}}$ Lonsény Traoré, ${ }^{\mathrm{c}}$ Patrick Poucheret, ${ }^{\mathrm{a}}{ }^{\dagger}$ \& Françoise Fons ${ }^{\mathrm{b}, *, \dagger}$

${ }^{a}$ Laboratoire de Pharmacologie et Physiopathologie Expérimentale, UMR Qualisud, CIRAD Université de Montpellier, Montpellier, France; ${ }^{b}$ Laboratoire de Botanique, Phytochimie et Mycologie, CEFE, CNRS - Université de Montpellier - Université Paul-Valéry Montpellier EPHE - IRD, Montpellier, France; ${ }^{c}$ Laboratoire de Technologie Alimentaire du Département de Génie Chimique de l’Université Gamal Abdel Nasser de Conakry, BP : 1147, Conakry, Guinée; ${ }^{\mathrm{d}}$ Laboratoire d’Immunologie, UMR Qualisud, CIRAD - Université de Montpellier, Montpellier,

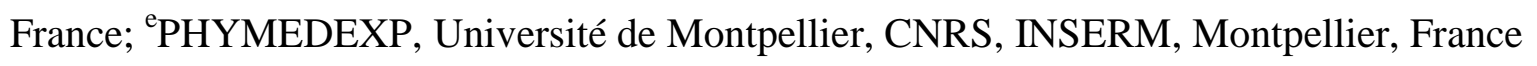
*Address all correspondance to: Françoise Fons, Laboratoire de Botanique, Phytochimie et Mycologie, CEFE, CNRS - Université de Montpellier — Université Paul-Valéry Montpellier — EPHE - IRD, Montpellier, France; Tel.: 33 (0) $4 \begin{array}{lllllll} & 4 & 96 & 60 & \text { E-mail: }\end{array}$ francoise.fons@umontpellier.fr

$\dagger$ These authors contributed equally to this work.

ABSTRACT: Lentinus edodes (=Lentinula edodes) is an edible mushroom grown and marketed for centuries due to its nutritional and medicinal properties. L. edodes has multiple pharmacological activities as antioxidant and anti-inflammatory. Few studies were performed taking into account the influence of culture conditions to optimize the biological properties of $L$. edodes on human health. Our work focused on the comparison of antioxidant capacity and anti- 
inflammatory activity of $L$. edodes fruit bodies cultivated by three mushroom producers in the French Occitanie region using the same strain in various growing conditions (organic and nonorganic). Sequential extraction was performed on freeze dried fungal materials. All extracts have a quantifiable but moderate antioxidant activity using the DPPH and ORAC tests. The antiinflammatory activity of the ethanol and aqueous extracts was evaluated on a model of inflammatory macrophages. The ethanol extracts inhibit NO production in a dose-dependent manner when the cells are pre-treated for $4 \mathrm{~h}$ with a $24 \mathrm{~h}$ stimulation time.

KEY WORDS: Lentinus edodes, anti-inflammatory, antioxidant, DPPH, food health benefit, J774.A1 macrophages, medicinal mushrooms, nitric oxide, ORAC, pharmacology

ABBREVIATIONS: APPH, 2,2'-azo-bis(2-methypropionamide); CA, chlorogenic acid; DMSO, dimethyl sulfoxide; DPPH, 1,1-diphenyl-2-picrylhydrazyl; IFN, Interferon gamma; LPS, lipopolysaccharide; NO, nitric oxide; ORAC, oxygen radical absorbance capacity; ROS, reactive oxygen species; RPMI, rosewell park memorial institute; TE, Trolox equivalent; TNFa, tumor necrosis factor alpha.

\section{INTRODUCTION}

Shiitake culinary-medicinal mushroom, Lentinus edodes (Berk.) Singer (=Lentinula edodes, Marasmiaceae, Agaricomycetes) is among the most edible cultivated mushrooms in the world. ${ }^{1-3}$ Its production is intensive in Asia, United States of America and in Europe. ${ }^{4,5}$ L. edodes can be grown using a wide range of conditions and substrates. L. edodes is appreciated for its fragrant taste and nutritional properties, and as medicinal mushroom. ${ }^{6-8}$

L. edodes is a source of bioactive agents as ergosterol, ${ }^{9}$ ergothioneine, ${ }^{10}$ phenolic compounds and polysaccharides, ${ }^{11,12}$ responsible for therapeutic activities (anti-inflammatory, antioxidant, antitumor, hypoglycemic). ${ }^{13-15}$ Several studies attributed this fungus the ability to 
inhibit or slow down the production of free radicals and to protect lipids against peroxidation due

to its content in antioxidant molecules. ${ }^{16-20}$ Others data reported that L. edodes has an inhibitory effect on NO production from LPS/IFN $\gamma$ activated macrophages explaining its anti-inflammatory potential. $^{21}$

The aim of our work is to compare the influence of L. edodes growing conditions using the same strain (cultivated by organic and non-organic French mushroom professionals) on its antioxidant and anti-inflammatory properties.

\section{MATERIAL AND METHODS}

\section{A. Chemicals}

Trolox (98\%), $\mathrm{NaH}_{2} \mathrm{PO}_{4}, 2$-amino-ethyl diphenyl borinate and acetic acid are from Fluka Chemicals. DPPH and AAPH radicals, chlorogenic acid (95\%), cyclohexane (99.8\%), acetonitrile, and dimethyl sulfoxide (DMSO; 99.9\%) were purchased from Sigma-Aldrich. Fluorescein is from Panreac. Ethanol (96\%) and methanol (99.9\%) are obtained from VWR. Chloroform (99\%) and $\mathrm{Na}_{2} \mathrm{HPO}_{4}$ (99\%) are from Honeywell Research Chemicals.

RPMI medium 1640 GlutaMAX®, penicillin-streptomycin, murine recombinant Interferon $\square$ Hank's Balanced Salt Solution (HBSS) and fetal bovine serum were obtained from Gibco. LPS E. coli 055: B5 and sodium nitroprusside were purchased from Sigma Aldrich. MTS (3-(4,5-dimethylthiazol-2-yl)-5-(3-carboxymethoxyphenyl)-2-(4-sulfophenyl)-2H-tetrazolium was purchased from Promega France. PMS (phenazinemethosulfate) was purchased from ICN Biomedical.

\section{B. Mushroom Material}

Mycelia-3782 strain of L. edodes was cultivated by three producers located in Occitanie (France) on sterilized substrate blocks from his own engineering (producer B) or provided from 
commercial suppliers (producers A and C). The L. edodes sporophores from producer A (Fontiès-d'Aude) grow on a mixture of wood chips and straw (non-organic conditions; substrate of Eurosubstrat $\left(\right.$ ) with temperatures ranging from 10 to $20^{\circ} \mathrm{C}$ and $80 \%$ hygrometry. The mushrooms generated by producer B (Saint-André-de-Lancize) are cultivated in the Cevennes National Park on organic sawdust of chestnut, wheat bran and rye (organic conditions) with temperatures ranging from 18 to $21^{\circ} \mathrm{C}$ and $60-70 \%$ hygrometry. The mushrooms from producer C (Saint-Bonnet-de-Salendrinque) grow on a mixture of wood chips, oak sawdust and straw (non-organic conditions, substrate of "Lentin de la buche" SA@) and temperatures vary from 15 to $17^{\circ} \mathrm{C}$ and $100 \%$ hygrometry.

\section{Sample Preparation}

Five kg of L. edodes from each producer were cleaned, sliced, gauged, and carefully packaged in plastic bags and snap frozen. Then they were lyophilized in a RP2V lyophilizer.

\section{Extract Production Process}

A sequential process based on solvents of increasing polarity is used as previously described. ${ }^{22}$ $50 \mathrm{~g}$ of each lyophilized mushroom sample are crushed with a Thermomix Vorwerk crusher. Then $5 \mathrm{~g}$ of crushed mushroom are placed in $50 \mathrm{ml}$ cyclohexane, sonicated for $90 \mathrm{~min}$ at $30^{\circ} \mathrm{C}$ and then filtered using a Büchner device. The cyclohexanic filtrate is stored for subsequent evaporation procedure: extract 1 . Retentate is then submitted successively to extractions with chloroform (50 mL, extract 2), ethanol (50 mL; extract 3) and water (50 mL; extract 4) under the same conditions. ${ }^{22}$ The sequential extraction is carried out in triplicate. After extractions, solvents were evaporated to dryness. To fully dry aqueous extracts, a lyophilization is performed. All dried extracts were stored in the darkness at $4^{\circ} \mathrm{C}$.

Extraction yields (R) were calculated according to formula as follows: 


$$
R=\frac{\text { Mass of dried extract in } \mathrm{g} * 100}{\text { Mass of dried mushroom in } \mathrm{g}}
$$

The values were expressed as a percentage.

Total yield was calculated as (Sum of masses of dried extracts/Mass of dried mushroom in $\mathrm{g}) \times 100$, and was expressed as a percentage.

\section{E. Antioxidant Activity}

\section{DPPH Test}

Antioxidant activity is assessed using the DPPH as previously described. ${ }^{22}$ Extracts are solubilized in DMSO (4 mg/mL) and then diluted in absolute ethanol to reach a concentration range of $0.2,0.5$ and $1 \mathrm{mg} / \mathrm{mL}$. Ethanol is used as blank. A standard curve with Trolox is performed (12.5, 25, 50 and $75 \mu \mathrm{M})$. Rosmarinus officinalis ethanol extract $(0.2 \mathrm{mg} / \mathrm{mL})$ and chlorogenic acid $(0.01 \mathrm{mg} / \mathrm{mL})$ are used as positive controls. On a 96 wells plate, $100 \mu \mathrm{L}$ of either a positive controls or mushroom extracts are deposited in each well. The assay is run in triplicate at each tested concentration. Then $75 \mu \mathrm{L}$ of absolute ethanol and $25 \mu \mathrm{L}$ of extemporaneously prepared DPPH $(0.4 \mathrm{mg} / \mathrm{mL})$ solution are introduced in each well. Plate is incubated for $30 \mathrm{~min}$ at room temperature and protected from light. Absorbance reading is performed at $550 \mathrm{~nm}$ with a microplate reader (MDS Inc., Toronto, Canada). Results are expressed as mean plus or minus standard deviation of three independent experiments and are expressed as Trolox equivalents (TE $\mu$ moles per gram of dry extract). Results are also expressed as inhibition percentage (\% inhibition) and was calculated as follows:

$$
\% \text { inhibition }=\frac{\text { DO blank }- \text { DO extract }}{\text { DO blank }} * 100
$$

\section{ORAC Test}

ORAC dosage is performed as previously described..$^{22}$ L. edodes samples are solubilized in 
DMSO to a concentration of $1 \mathrm{mg} / \mathrm{mL}$. They are then diluted to $25 \mu \mathrm{g} / \mathrm{mL}$ using a phosphate buffer solution $(75 \mathrm{mM})$ at $\mathrm{pH}$ 7.4. On a 96 wells microplate, are deposited Trolox standard curve solutions (20 $\mu \mathrm{L}$ at $6.25,12.5,25,50$ and $75 \mu \mathrm{M}$ ), or chlorogenic acid (0.01 mg/mL), or rosemary ethanol extract $(12.5 \mu \mathrm{g} / \mathrm{mL})$ as positive control, or shiitake extracts from all producers at a concentration of $25 \mu \mathrm{g} / \mathrm{mL}$. Then $100 \mu \mathrm{L}$ of phosphate buffer and $100 \mu \mathrm{L}$ of extemporaneously prepared fluorescein solution $(0.1 \mu \mathrm{M}$ in phosphate buffer) are added. Microplate is incubated at $37^{\circ} \mathrm{C}$ for 10 min under stirring. Reaction is initiated with $50 \mu \mathrm{L}$ of AAPH extemporaneously prepared. Fluorescence is recorded at an excitation wavelength of 485 nm and an emission wavelength of $535 \mathrm{~nm}$, for 70 min using a microplate reader Tristar LB 941. Final ORAC values are calculated using a regression equation between Trolox concentration and the area under the curve of fluorescein decreasing. Data are expressed as $\mu$ moles of Trolox equivalents per gram of dry extract. Results avec expressed as mean plus or minus standard deviation $(\mathrm{n}=3)$.

\section{F. Anti-inflammatory Assay}

\section{Macrophage Culture and Cell Treatment}

The J774.A1 macrophage cell line (ATCC, TIB67) was obtained from LGC Standards. Cells were cultured in RPMI medium 1640 GlutaMAX ${ }^{\circledR}$ supplemented with streptomycin (100 $\mu \mathrm{g} / \mathrm{mL}$ ) and penicillin (100 Units/mL) and 10\% heat inactivated fetal bovine serum (complete RPMI medium), and incubated at $37^{\circ} \mathrm{C}$ in a humidified incubator containing $5 \% \mathrm{CO}_{2}$. For NO production, the cells ( $5 \times 10^{5}$ cells/well) were seeded onto a 24 -well culture plate in complete RPMI medium and pretreated with different concentrations of ethanol or aqueous extracts (50 to $6.25 \mu \mathrm{g} / \mathrm{mL})$ for $4 \mathrm{~h}$. After, cells were activated with LPS (100 $\mathrm{ng} / \mathrm{mL})$ and Interferon $\gamma(10$ $\mathrm{ng} / \mathrm{mL}$ ) and incubated at $37^{\circ} \mathrm{C}$ for another $18 \mathrm{~h}$. 


\section{Cell Viability by MTS Assay}

In order to test the cytotoxicity, $10^{5}$ cells/well was seeded in a 96-well culture plate in complete RPMI medium and incubated at $37^{\circ} \mathrm{C}$ with different concentrations of ethanol or aqueous extracts (50 to $6.25 \mu \mathrm{g} / \mathrm{mL}$ ) for $20 \mathrm{~h}$. After incubation, $20 \mu \mathrm{L} /$ well of tetrazolium salt, MTS, mixed with an electron coupling reagent, PMS in HBSS, was added. The plate was incubated for another $4 \mathrm{~h}$ and the absorbance at $490 \mathrm{~nm}$ was measured in a microplate reader (Molecular Devices) as previously described. ${ }^{23}$

\section{Nitrite Determination}

Ethanol and aqueous extracts was used for nitrite determination. The presence of nitrite, a stable oxidized product of nitric oxide, was determined in cell culture media as previously described. ${ }^{24}$ Briefly, $100 \mu \mathrm{L}$ of supernatant was combined with $100 \mu \mathrm{L}$ of Griess reagent in a 96-well plate, incubated $10 \mathrm{~min}$ at room temperature. Nitrite concentration was determined by measuring the absorbance at $550 \mathrm{~nm}$ and by using a standard curve of $\mathrm{NaNO}_{2}(1-100 \mu \mathrm{M})$.

\section{G. Statistical Analyses}

Values are presented as mean \pm standard error of the mean (SEM). Statistical analysis of the data was carried out using Prism ${ }^{\circledR}$ software by two-way ANOVA followed by Bonferroni posttest. $P$ values $<0.05$ were considered to be significant.

\section{RESULTS}

\section{A. Extraction and Extraction Yield}

A sequential extraction was used to get the broader spectrum of bioactive molecules from the shiitake materials. Total yield of the fourth extractions were 21.88, 28.58 and $24.73 \%$ for producers A, B and C, respectively. For all producers, the highest extraction yields are obtained for aqueous extracts (extracts 4 ranging from $13.45 \%$ for producer A to $19.52 \%$ for producer B) 
followed by the ethanol extracts (extracts 3). No significant differences of extraction yields were found between the three producers for extracts 1, 2 and 3; the aqueous extract yield for organic producer B was significantly higher than that of the other two producers (Fig. 1).

\section{B. Antioxidant Activities}

The DPPH and ORAC tests results on our extracts (Table 1) were compared with two positive controls in terms of antioxidant activity: an ethanolic extract of $R$. officinalis that has been considered as a food antioxidant additive (E392) and chlorogenic acid (CA), a caffeic acid derivative. ${ }^{22}$ Rosemary extract was used as a reference of natural crude extract and CA as a natural purified standard.

\section{DPPH Antioxidant Activity}

Results from the DPPH test (Table 1, Fig. 2) are expressed as percentage of inhibition and as Trolox equivalents (TE). Trolox is used as positive control. Shiitake extracts demonstrate an antioxidant effect ranging from 11.54 to $34.73 \mu \mathrm{mol} \mathrm{TE} / \mathrm{g}$ of extract. These values are, in average, 22 times lower than rosemary extract antioxidant potential $(261.67 \mu \mathrm{mol} \mathrm{TE} / \mathrm{g}$ of extract). If all mushroom extracts $(1,2,3,4)$ demonstrate moderate DPPH antioxidant activity, aqueous extracts appear the most antioxidant whatever the producer when compared with the organic extracts: $34.73 \mu \mathrm{mol} \mathrm{TE} / \mathrm{g}$ for producer A, $25.82 \mu \mathrm{mol} \mathrm{TE} / \mathrm{g}$ for producer B, $30.64 \mu \mathrm{mol}$ TE/g for producer C. The average value is 8.6 times lower than rosemary extract antioxidant effect and 100 times lower than CA antioxidant effect (3077.4 $\mu \mathrm{mol}$ TE/g of standard) (Fig. 2). In addition, cyclohexane, chloroform and ethanol extracts from producer A have statistically the highest DPPH antioxidant ability when compared to producer C. Cyclohexane and aqueous extracts from producer A have statistically the highest DPPH antioxidant ability when compared to producer B (Fig. 2). Cyclohexane extract from B and chloroform extract from producer C 
have the lowest DPPH antioxidant capacities with 12.88 and $11.54 \mu \mathrm{mol} \mathrm{TE} / \mathrm{g}$, respectively. It should be noted that when comparing producers, the highest DPPH antioxidant properties are recorded with non-organic producer A, whatever the type of extract. However, there is no significant difference between producer A and B regarding their ethanol extracts with values of 26.63 and $22.78 \mu \mathrm{mol} \mathrm{TE} / \mathrm{g}$, respectively. About organic producer B, DPPH antioxidant potential of extracts increases with extracts polarity whereas no correlation can be done between polarity of the extracts and DPPH values for non-organic producers A and C.

\section{Oxygen Radical Absorbance Capacity (ORAC) Antioxidant Activity}

Results are expressed in $\mu$ mol of Trolox Equivalents (TE) per gram of dry matter. Similarly, to $\mathrm{DPPH}$, results from ORAC indicate that aqueous extracts have the highest ORAC antioxidant activity for all producers (684, 749 and $892 \mu \mathrm{mol} \mathrm{TE/g} \mathrm{for} \mathrm{producers} \mathrm{A,} \mathrm{B} \mathrm{and} \mathrm{C,} \mathrm{respectively)}$

(Table 1). These values are followed by those of the cyclohexane extract for producer A and chloroform extracts for producers B and C. There is no significant difference between ORAC values of cyclohexane, chloroform and ethanol extracts from producers A (non-organic) and B (organic) as shown (Fig. 3). All extracts from non-organic producer C have significantly higher ORAC values when compared with two other producers. The highest average value of ORAC antioxidant activity for shitake extracts were three times lower than rosemary activity (2560 $\mu \mathrm{mol} \mathrm{TE} / \mathrm{g}$ EDW) and 15 times lower than CA (11515 $\mu \mathrm{mol}$ TE/g EDW), respectively.

\section{Anti-inflammatory Activity}

Apolar extracts were not investigated for their anti-inflammatory properties due to poor solubility at $10 \mathrm{mg} / \mathrm{mL}$ in DMSO.

\section{L. edodes Aqueous and Ethanol Extracts Effects on Cell Viability}

DMSO was used to solubilize the extracts at $10 \mathrm{mg} / \mathrm{mL}$ and then diluted in RPMI to reach a 
concentration range from 50 to $6.25 \mu \mathrm{g} / \mathrm{mL}$. L. edodes extracts assay on cell viability, performed on macrophage cell line J774.A1 using the MTS/PMS method, demonstrate the absence of cytotoxic effect on cells. Indeed, none of the concentrations tested, ranging from 50 to 6.25 $\mu \mathrm{g} / \mathrm{mL}$ during $4 \mathrm{~h}$ incubation, impaired cell culture when compared to control cells (data not shown). In consequence, these extracts concentrations are tested on NO production by activated macrophages in vitro.

\section{L. edodes Aqueous and Ethanol Extracts Effects on Nitric Oxide (NO) Production}

$\mathrm{NO}$ is an unstable mediator of inflammation. Upon production by cells it is readily converted in nitrites that can be dosed by Griess colorimetric method. Anti-inflammatory effects of ethanol extracts are assessed on stimulated macrophage J774.A1. After cells stimulation by LPS/IFN $\gamma$, nitrite production, is quantified in the cell culture supernatant. Extracts concentrations range from 50 to $6.25 \mu \mathrm{g} / \mathrm{mL}$. We record that LPS/IFN $\gamma$ strongly stimulates NO production by macrophages as expected.

Ethanol extracts from the three producers significantly inhibit NO production in a concentration dependent manner (Fig. 4). At $50 \mu \mathrm{g} / \mathrm{mL}$, inhibition reaches 29.66, 31.30 and 27.56\% for producers A, B and C, respectively, on cells pre-treated by extracts for $4 \mathrm{~h}$ with stimulation time of $24 \mathrm{~h}$. It should be noted that NO production is also concentration dependently decreased after the $48 \mathrm{~h}$ stimulation condition but in this case the effect is globally more important at the highest concentration (41.6, 42.6 and 39\% for producers A, B and C, respectively). When comparing producers, anti-inflammatory potential appears equivalent showing no statistical differences. Results presented in Fig. 4 shown that cell pretreatment with shiitake aqueous extract induced a low inhibition of nitrite production and this effect was concentration dependent. The highest values after $4 \mathrm{~h}$ pretreatment with $24 \mathrm{~h}$ of stimulation were 
14.23, 15.60 and $20.93 \%$ for producers A, B and C, respectively at $50 \mu \mathrm{g} / \mathrm{mL}$. About $48 \mathrm{~h}$ stimulation, results indicate 17.1, 15.22 and $18.71 \%$ for producers $\mathrm{A}, \mathrm{B}$ and $\mathrm{C}$ at higher concentration, respectively. When comparing producers or stimulation time (24 h and $48 \mathrm{~h}$ ), we found no statistically differences (data not shown).

The NO inhibition activities of aqueous and ethanol extracts of $L$. edodes were compared. They were the highest for the ethanol extracts whatever the producer or concentration used; a significant difference was only observed between producers A and B $(p<0.05)$ at the concentration of $50 \mu \mathrm{g} / \mathrm{mL}$ (data not shown).

\section{DISCUSSION}

In order to extract bioactive molecules from various cultivated L. edodes strain (Mycelia-3782) conditions, a sequential extraction was performed using cyclohexane, chloroform, ethanol and water. Aqueous and ethanol extracts generated the highest extraction yields. Differences of total extraction efficiency for each solvent and producer may be explained by growing conditions influence, stage of harvest as well as mushroom size. ${ }^{25}$ Methanol, ethanol, water and hydroethanolic mixes are the most commonly used solvents, for the extraction of bioactive molecules, since they allow to reach high yields. ${ }^{26}$ Few studies reported chloroform and cyclohexane to extract secondary metabolites on L. edodes mushroom. ${ }^{26,27}$ Extraction yields for water extracts from producers A, B and C (13.45, 19.52 and 15.36\%, respectively) were similar to data from Cheung et al., ${ }^{16}$ (16.2\%) but lower than those reported by Da Silva and Jorge (30\%). ${ }^{28}$ Our results for chloroform extracts ranged from 0.68 to $1.15 \%$ and from 6.49 to $7.49 \%$ for ethanol extracts. More recently, Ferrari et al., ${ }^{29}$ using a non-sequential extraction, recorded extraction yields of 11, 13.6, 14, 27.2, 32.7 and 33.8\% with ethanol, methanol, acetone, ethanol-water, methanol-water and acetone-water, respectively. The differences between our data and the 
literature may be explained by differences in extraction methods, mushroom strain and growth conditions when compared with literature.

In our study, we used two complementary methods, i.e., DPPH as the mixed mode assay (hydrogen atom transfer and electron transfer reaction-based assay) and ORAC as a hydrogen atom transfer reaction-based assay to evaluate antioxidant properties of shiitake. ${ }^{22}$ DPPH assay results indicate that all shiitake extracts demonstrate a moderate but quantifiable antioxidant activity. With an extract concentration of $1 \mathrm{mg} / \mathrm{mL}$, the inhibition levels of the ethanolic $L$. edodes extracts (17.6, 17.16 and 10.31\% from producers A, B and C, respectively; Table 1) were similar to those reported by Da Silva and Jorge. ${ }^{28}$ Regarding cyclohexane extracts, our results suggest a lower inhibitory ability for mushroom material from producers A, B and C (18, 10 and $11 \%$, respectively) when compared to literature. ${ }^{27} \mathrm{~A}$ large variety of shiitake extracts were tested for their antioxidant potential using DPPH assay; nonetheless most studies were performed on aqueous, ethanolic and hydro-ethanolic extracts. ${ }^{7,16,20}$ Regarding antioxidant efficacy against DPPH radicals, hydro- ethanolic extract demonstrated the highest potential. ${ }^{29}$

Few investigations were performed on $L$. edodes with the ORAC assay. Our results ranged from 442 to $892 \mu \mathrm{mol} \mathrm{TE} / \mathrm{g}$ of extract (Table 1). Previous studies recorded various ORAC values expressed with different units..$^{30,31,32}$ DPPH and ORAC are quantitative assays allowing to compare radical scavenging capacities between extracts as well as producers. Our results, and their comparison to data from the literature, clearly indicate that shiitake biological activity as antioxidant capacity may vary significantly as a function of mushroom strain, growth conditions, extraction process and experimental conditions of biological activities evaluation. Plant extracts (as rosemary extract, the E392) or purified natural compounds (as chlorogenic acid) may be used as food additives. Several authors demonstrated indeed that chlorogenic acid 
and related compounds can mitigate oxidative and inflammatory stresses and show several health promoting properties. ${ }^{33}$ That's why there were used as positive controls in our investigations for oxidant and inflammatory potential of L. edodes.

In addition to antioxidant effects, shiitake ethanol extracts demonstrate an inhibitory activity on NO production from LPS/IFN $\gamma$ activated macrophages J774.A1. This result indicates that shiitake extracts have an anti-inflammatory potential in vitro. Ethanol extracts from the three producers, at a concentration of $50 \mu \mathrm{g} / \mathrm{mL}$, inhibit $\mathrm{NO}$ production in concentration dependent manner (41.6, 42.6 and 39\% inhibition for producers A, B and C, respectively) on 4 h pre-treated cells with a stimulation time of $48 \mathrm{~h}$. Phenolic compounds and ergothioneine extracted by ethanolic or hydro-ethanolic solvent, might be responsible for this effect as previously suggested. ${ }^{19,21}$ These results are in agreement with those reported by authors ${ }^{34,35}$ studying the effect of an ethanolic shiitake extract on NO inhibition.

Several mechanisms of action for inhibition of NO production are described in the literature such as NF- $\mathrm{BB}$, a transcription factor composed of a protein complex, located in cytoplasm and associated with the inhibitor IкB. ${ }^{36,37}$ In response to various stimuli such as pro-

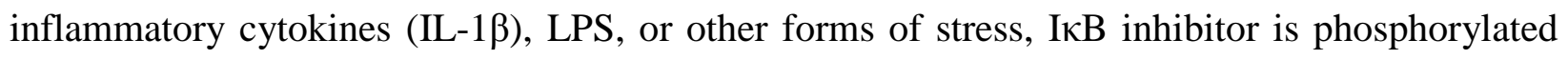
by the IKK kinase and then degraded. ${ }^{36,38}$ This degradation promotes the activation of NF- $\mathrm{KB}$ and its release to join the nucleus where it attaches to inflammatory genes and activates the transcription of specific genes. ${ }^{39,40}$ This will lead to synthesis of cytokines and inflammatory mediators including TNF- $\alpha$ and NO. ${ }^{38} \mathrm{NF}-\mathrm{\kappa B}$ transcription factor plays an important role in immune response and then inflammation. Consequently, its deregulated activation contributes to the pathogenic processes of various inflammatory diseases. ${ }^{40,41}$ Therefore, inhibition of this pathway prevents or decreases the synthesis of pro-inflammatory cytokines. ${ }^{37,38,41}$ 
In our work, the inhibition would be associated with a decreased expression of iNOS (induced nitric oxide synthase) responsible for NO production. ${ }^{42}$ A cytotoxic impact of the shiitake extracts on cells was ruled out by the cell viability test that produced negative results. Inflammation reaction being a complex process involving many mediators such as cytokines, in addition to NO, further molecular investigations are required to fully understand the pharmacology of antioxidant and anti-inflammatory properties of L. edodes extracts.

\section{CONCLUSIONS}

Our study focused on the antioxidant and anti-inflammatory potential of $L$. edodes fruit bodies cultivated by non-organic and organic mushroom professionals using the same strain. The $L$. edodes extracts from the three French mushroom producers obtained by a sequential extraction showed moderate antioxidant activity with greater free radical inhibition in aqueous extracts. Regarding the anti-inflammatory property of the polar extracts tested, all ethanolic extracts strongly inhibit NO production in a concentration-dependent manner thus suggesting L. edodes potential interest in the treatment against certain types of non-communicable diseases. On the other hand, the inhibition observed for aqueous extracts remains low whatever organic and nonorganic producers. Concerning the shiitake growing conditions used, our study shows some significant differences in the antioxidant and anti-inflammatory activities among the L. edodes extracts from the three mushroom producers. Other growing conditions will need to be tested both organic and non-organic to improve differences. In addition, further investigations should be carried out to identify the main bioactive components of cultivated $L$. edodes extracts responsible for the antioxidant capacity and anti-inflammatory activity, and especially to study their mechanism of action.

\section{ACKNOWLEDGMENTS}


Thanks are extended to R. Loubet, C. Veenstra and V. Lehnebach for supplying the fresh $L$. edodes mushrooms and reporting cultivation methods. This study was financially supported by the French Embassy in Guinea (Campus France).

\section{REFERENCES}

1. Wasser SP. Medicinal mushroom science: history, current status, future trends, and unsolved problems. Int J Med Mushrooms. 2010;12(1):1-16.

2. Gaitan-Hernandez R, Zavaleta MAB, Aquino-Bolaños EN. Productivity, physicochemical changes, and antioxidant activity of shiitake culinary-medicinal mushroom Lentinus edodes (Agaricomycetes) cultivated on lignocellulosic residues. Int $\mathrm{J}$ Med Mushrooms. 2017;19(11):1041-52.

3. Kupcova K, Stefanova I, Plavcova Z, Hosek J, Hrouzek P, Kubec R. Antimicrobial, cytotoxic, anti-inflammatory, and antioxidant activity of culinary processed Shiitake medicinal mushroom (Lentinus edodes, Agaricomycetes) and its major sulfur sensory-active compound-lenthionine. Int J Med Mushrooms. 2018;20(2):165—75.

4. Bernaś E, Jaworska G, Kmiecik W. Storage and processing of edible mushrooms. Acta Sci Pol Technol Aliment. 2006;5(2):5—23.

5. Chakravarty B. Trends in mushroom cultivation and breeding. AJAE. 2011;2(4):102—9.

6. Chang ST, Wasser SP. Current and future research trends in agricultural and biomedical applications of medicinal mushrooms and mushroom products. Int J Med Mushrooms. 2018;20(12):1121—33.

7. Mata G, Valdez K, Mendoza R, Trigos A. HS/GC-MS analyzed chemical composition of the aroma of fruiting bodies of two species of genus Lentinus (higher Basidiomycetes). Int J Med Mushrooms. 2014;16(5):477—84. 
8. Wasser SP, Nevo E, Sokolov D, Reshetnikov S, Timor-Tismenetsky M. Dietary supplements from medicinal mushrooms: diversity of types and variety of regulations. Int $\mathrm{J}$ Med Mushrooms. 2000;2(1):1-19.

9. Mattila P, Salo-Väänänen P, Könkö K, Aro H, Jalava T. Basic composition and amino acid contents of mushrooms cultivated in Finland. J Agric Food Chem. 2002;50(22):6419—22.

10. Dubost NJ, Ou B, Beelman RB. Quantification of polyphenols and ergothioneine in cultivated mushrooms and correlation to total antioxidant capacity. Food Chem. 2007;105(2):727-35.

11. Reis FS, Martins A, Barros L, Ferreira IC. Antioxidant properties and phenolic profile of the most widely appreciated cultivated mushrooms: A comparative study between in vivo and in vitro samples. Food Chem Toxicol. 2012;50(5):1201-7.

12. Chang ST, Wasser SP. The role of culinary-medicinal mushrooms on human welfare with a pyramid model for human health. Int J Med Mushrooms. 2012;14(2):95-134.

13. Poucheret P, Fons F, Rapior S. Biological and pharmacological activity of higher fungi: 20year retrospective analysis. Cryptogamie, Mycol. 2006;27(4):311—33.

14. Lo H-Ch, Wasser SP. Medicinal mushrooms for glycemic control in diabetes mellitus: history, currenr status, future perspectives, and unsolved problems (review). Int J Med Mushrooms. 2011; 13(5): 401-26.

15. De Silva DD, Rapior S, Sudarman E, Stadler M, Xu J, Alias AS, Hyde KD. Bioactive metabolites from macrofungi: ethnopharmacology, biological activities and chemistry. Fungal Divers. 2013;62:1—40.

16. Cheung LM, Cheung PCK, Ooi VEC. Antioxidant activity and total phenolics of edible mushroom extracts. Food Chem. 2003;81(2):249—55. 
17. Mujic I, Zekovic Z, Lepojevic Ž, Vidovic S, Živkovic J. Antioxidant properties of selected edible mushroom species. J Cent Eur Agric. 2010;11(4):387-92.

18. Shao S, Hernandez M, Kramer JKG, Rinker DL, Tsao R. Ergosterol profiles, fatty Acid composition, and antioxidant activities of button mushrooms as affected by tissue part and developmental stage. J Agric Food Chem. 2010;58(22):11616-25.

19. Benson KF, Ager DM, Landes B, Aruoma OI, Jensen GS. Improvement of joint range of motion (ROM) and reduction of chronic pain after consumption of an ergothioneinecontaining nutritional supplement. Prev Med. 2012;54:S83—S89.

20. Choi EJ, Park ZY, Kim EK. Chemical composition and inhibitory effect of Lentinula edodes ethanolic extract on experimentally induced atopic dermatitis in vitro and in vivo. Molecules. 2016;21(8):993-98.

21. Gunawardena D, Bennett L, Shanmugam K, King K, Williams R, Zabaras D, Head R, Ooi L, Gyengesi G, Münch G. Anti-inflammatory effects of five commercially available mushroom species determined in lipopolysaccharide and interferon- $\gamma$ activated murine macrophages. Food Chem. 2014;148:92-96.

22. Morel S, Arnould S, Vitou M, Boudard F, Guzman C, Poucheret P, Fons F, Rapior S. Antiproliferative and antioxidant activities of wild Boletales mushrooms from France. Int $\mathrm{J}$ Med Mushrooms. 2018;20(1):13—29.

23. Almaksour Z, Boudard F, Villareal M, Grosmaire L, Guzman C, Isoda H, Larroque M, Margout D. Anti-inflammatory and anti-oxidant activities of different extra virgin olive oil varieties extracts. AJMAP. 2017;3(2):163—83.

24. Boudard F, Vallot N, Cabaner C, Bastide M. Chemiluminescence and nitrite determination of MALU macrophage cell line. J Immunol Methods. 1994;174(1—2):259—268. 
25. Vitrac V, Reignier A, Henry-Vitrac C, Minvielle N, Mérillon JM, Savoie JM. Changes in antioxidant activities and compounds during cultivation of Shiitake (Lentinula edodes). Proceedings of the 7th International Conference on Mushroom Biology and Mushroom Products (ICMBMP7); 2011 Oct 4—7; Arcachon, France. Paris: INRA, 2011.

26. Kalyoncu F, Oskay M, Kayalar H. Antioxidant activity of the mycelium of 21 wild mushroom species. Mycology. 2010;1(3):195-199.

27. Rahman MA, Abdullah N, Aminudin N. Lentinula edodes (Shiitake mushroom): An assessment of in vitro anti-atherosclerotic bio-functionality. Saudi J Biol Sci. 2018;25(8):1515-23.

28. Da Silva AC, Jorge N. Antioxidant properties of Lentinus edodes and Agaricus blazei extracts. J Food Qual. 2011;34:386-94.

29. Ferrari GP, Soares AA, Bazanella GCD, Bracht A, De Souza CGM, Boer CG, Peralta RM. Antioxidant properties of the most common edible mushrooms consumed in Brazil. In book: Mushrooms: Types, Properties and Nutrition. New York: Nova Science Publishers Inc., 2012, p. 285-97.

30. Kettawan A, Chanlekha K, Kongkachuichai R, Charoensiri R. Effects of cooking on antioxidant activities and polyphenol content of edible mushrooms commonly consumed in Thailand. Pak J Nutr. 2011;10(11):1094-1103.

31. Ito T, Kato M, Tsuchida H, Harada E, Niwa T, Osawa T. Ergothioneine as an antioxidative/anti-inflammatory component in several edible mushrooms. Food Sci Technol Res. 2011;17 (2):103-10.

32. United States International Trade Commission (USITC). Mushrooms industry \& trade summary. Office of Industries Publication ITS-07, Washington, USA, 2010. 
33. Santana-Gálvez J, Cisneros-Zevallos L, Jacobo-Velázquez DA. Chlorogenic acid: recent advances on its dual role as a food additive and a nutraceutical against metabolic syndrome. Molecules. 2017;22(3):358-63.

34. Chien RC, Lin LM, Chang YH, Lin YC, Wu PH, Asatiani MD, Wasser SG, Krakhmalnyi M, Agbarya A, Wasser SP, Mau JL. Anti-inflammation properties of fruiting bodies and submerged cultured mycelia of culinary-medicinal higher Basidiomycetes mushrooms. Int J Med Mushrooms. 2016;18(11):999—1009.

35. Xu X, Yasuda M, Nakamura-Tsuruta S, Mizuno M, Ashida H. $\beta$-Glucan from Lentinus edodes inhibits nitric oxide and tumor necrosis factor- $\alpha$ production and phosphorylation of mitogen-activated protein kinases in lipopolysaccharide-stimulated murine RAW 264.7 macrophages. J Biol Chem. 2012;287(2):871—78.

36. Baud V, Jacque E. Voie alternative d'activation de NF-kB et cancer. Amis ou ennemis? Méd Sci. 2008;24(12):1083-88.

37. Suryavanshi SV, Kulkarni YA. NF- $\kappa \beta$ : A potential target in the management of vascular complications of diabetes. Front Pharmacol. 2017;8:798-803.

38. Bonizzi G, Karin M. The two NF-kB activation pathways and their role in innate and adaptive immunity. Trends Immunol. 2001;25(6):280—88.

39. Tak PP, Firestein GS. NF-kB: a key role in inflammatory diseases. J Clin Invest. 2001;107(1):7-11.

40. Baker RG, Hayden MS, Ghosh S. NF-kB, inflammation, and metabolic disease. Cell Metabolism. 2011;13(1):11-22.

41. Liu T, Zhang L, Joo D, Sun SC. NF-kB signaling in inflammation. Signal Transduct Target Ther. 2017;2:17023. 
42. Pacheco-Sánchez M, Boutin Y, Angers P, Gosselin A, Tweddell RJ. Inhibitory effect of CDP, a polysaccharide extracted from the mushroom Collybia dryophila, on nitric oxide synthase expression and nitric oxide production in macrophages. Eur J Pharmacol. 2007;555(1):61—66.

TABLE 1: Antioxidant Capacity of Lentinus edodes Extracts from Organic and Non-Organic French Producers

\begin{tabular}{|c|c|c|c|c|c|}
\hline \multirow[t]{2}{*}{ Producers } & \multirow[t]{2}{*}{ Extracts } & \multicolumn{3}{|c|}{ DPPH } & \multirow{2}{*}{$\begin{array}{c}\text { ORAC } \\
\mu \mathrm{mol} \text { TE/g EDW }\end{array}$} \\
\hline & & $\begin{array}{c}\mathrm{EC}_{50} \\
(\mathrm{mg} / \mathrm{mL})\end{array}$ & $\begin{array}{l}\text { Inhibition } \\
\text { (\%) at } 1 \\
\text { mg/mL }\end{array}$ & $\mu \mathrm{mol}$ TE/g EDW & \\
\hline \multirow{4}{*}{ A } & Extract 1 & $>1$ & $18 \pm 1.14$ & $25.88 \pm 1.71$ & $520 \pm 25$ \\
\hline & Extract 2 & $>1$ & $16.37 \pm 0.14$ & $21.7 \pm 0.65$ & $442 \pm 16$ \\
\hline & Extract 3 & $>1$ & $17.6 \pm 0.84$ & $26.63 \pm 1.96$ & $494 \pm 6$ \\
\hline & Extract 4 & $>1$ & $25.23 \pm 3.44$ & $34.73 \pm 2.82$ & $684 \pm 52$ \\
\hline \multirow{4}{*}{$\mathrm{B}$} & Extract 1 & $>1$ & $10.03 \pm 1.02$ & $12.88 \pm 0.98$ & $549 \pm 15$ \\
\hline & Extract 2 & $>1$ & $12.41 \pm 0.65$ & $16.94 \pm 0.67$ & $578 \pm 30$ \\
\hline & Extract 3 & $>1$ & $17.16 \pm 0.95$ & $22.78 \pm 0.77$ & $528 \pm 44$ \\
\hline & Extract 4 & $>1$ & $18.4 \pm 1.09$ & $25.82 \pm 0.27$ & $749 \pm 38$ \\
\hline \multirow{4}{*}{$\mathrm{C}$} & Extract 1 & $>1$ & $11 \pm 0.21$ & $15.52 \pm 0.83$ & $752 \pm 22$ \\
\hline & Extract 2 & $>1$ & $8.7 \pm 0.54$ & $11.54 \pm 0.89$ & $859 \pm 22$ \\
\hline & Extract 3 & $>1$ & $10.31 \pm 0.63$ & $14.01 \pm 0.79$ & $747 \pm 28$ \\
\hline & Extract 4 & $>1$ & $24 \pm 1.18$ & $30.64 \pm 2.03$ & $892 \pm 21$ \\
\hline \multicolumn{2}{|c|}{ Rosmarinus officinalis } & $0.32 \pm 0.01$ & n.d. & $261.67 \pm 0.65$ & $2560 \pm 216$ \\
\hline \multicolumn{2}{|c|}{ Chlorogenic acid } & n.d. & n.d. & $3077.4 \pm 129.94$ & $11515 \pm 994$ \\
\hline
\end{tabular}

Data are mean \pm SEM $(n=3)$. EC 50 , half-maximal effective concentration; EDW: extract dry weight; TE: Trolox equivalent; n.d.: not determined. 
FIG. 1: Extraction yields for producers A, B and C. Values are presented as mean \pm SEM ( $n=3)$. Extract 1 = cyclohexane extracts; Extract 2 = chloroform extracts; Extract 3 = ethanol extracts; Extract 4 = aqueous extracts. Extraction yields (R) were calculated according to this formula: (Mass of dried extract in $\mathrm{g} /$ Mass of dried mushroom in $\mathrm{g}$ ) $\times 100$, and was expressed as a percentage; ${ }^{* * *} p<0.001$ for producer A versus producer $\mathrm{B} ;{ }^{\$ \$ \$} p<0.001$ for producer B versus producer C.

FIG. 2: DPPH values for producers A, B and C. Values are presented as mean \pm SEM $(n=3)$. Extract 1 = cyclohexane extracts; Extract 2 = chloroform extracts; Extract 3 = ethanol extracts; Extract 4 = aqueous extracts. ${ }^{* * *} p<0.001$ for producer A versus producer $\mathrm{B} ;{ }^{\$ \$} p<0.001$ for producer A versus producer $\mathrm{C}$; ${ }^{\#} p<0.05,{ }^{\# \#} p<0.001$ for producer B versus producer $\mathrm{C}$.

FIG. 3: ORAC values for producers A, B and C. Values are presented as mean \pm SEM $(n=3)$. Extract 1 = cyclohexane extracts; Extract 2 = chloroform extracts; Extract 3 = ethanol extracts; Extract 4 = aqueous extracts. ${ }^{* *} p<0.01,{ }^{* * *} p<0.001$ for producer A versus producer $\mathrm{C}$; ${ }^{\$} p<0.05$, ${ }^{\$} p<0.01,{ }^{\$ \$} p<0.001$; for producer B versus producer C.

FIG. 4: The bar graphs summarize the NO inhibition for producers A, B and C after $4 \mathrm{~h}$ pretreatment with $24 \mathrm{~h}$ of stimulation, (a) by ethanolic extracts or (b) by aqueous extracts. Values are presented as mean $\pm \operatorname{SEM}(\mathrm{n}=3)$. ${ }^{* * *} p<0.001$, inhibition resulting from $50 \mu \mathrm{g} / \mathrm{mL}$ of extract vs. no inhibition; ${ }^{\$} p<0.05,{ }^{\$} p<0.01,{ }^{\$ \$} p<0.001$, inhibition resulting from $25 \mu \mathrm{g} / \mathrm{mL}$ of extract vs. no inhibition; ${ }^{£ £} p<0.01$, inhibition resulting from $12.5 \mu \mathrm{g} / \mathrm{mL}$ of extract vs. no inhibition; ${ }^{\alpha} p<0.05$, inhibition resulting from $6.25 \mu \mathrm{g} / \mathrm{mL}$ of extract vs. no inhibition. 

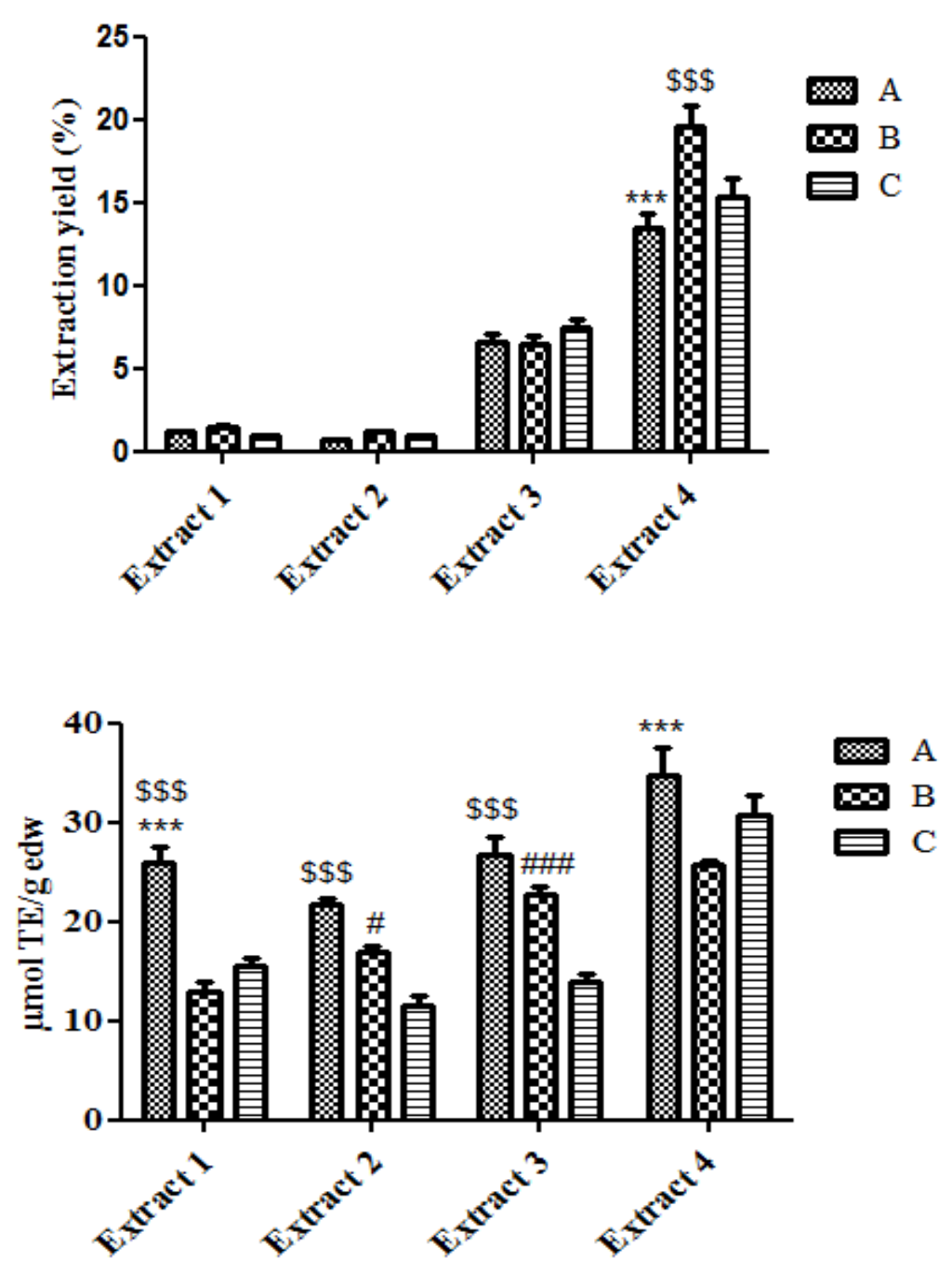


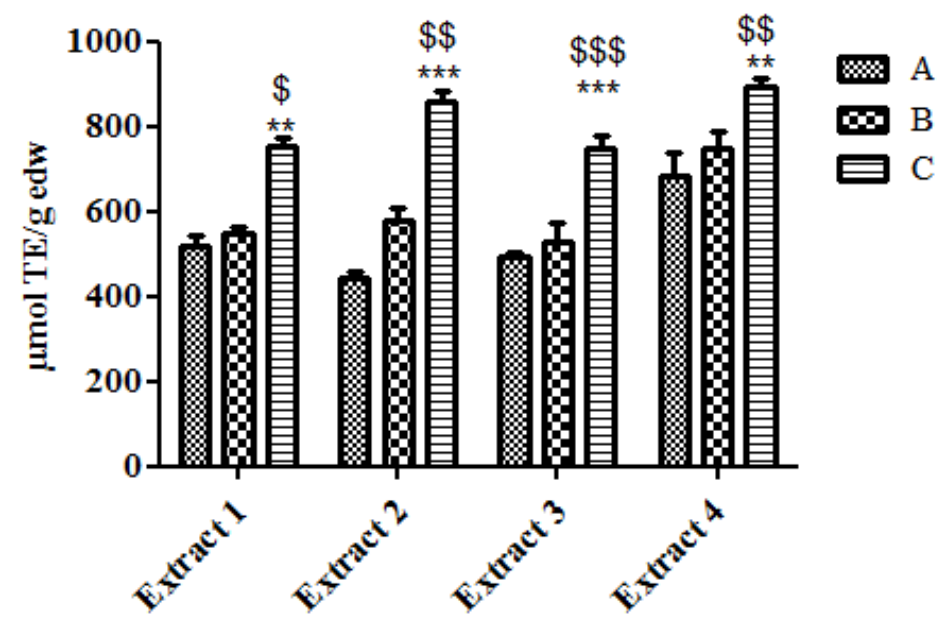

a

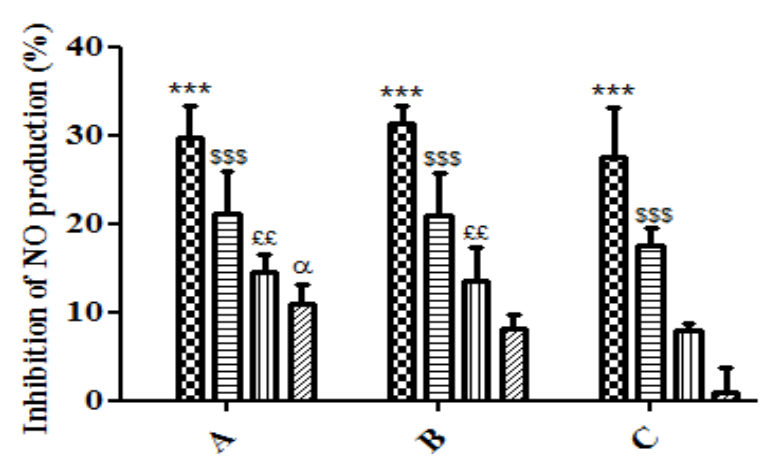

b

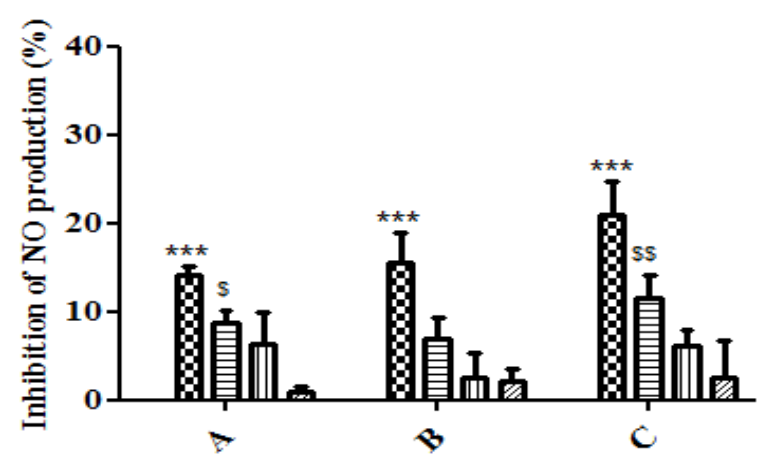

$50 \mu \mathrm{g} / \mathrm{mL}$

口 $25 \mu \mathrm{g} / \mathrm{mL}$

에 $12.5 \mu \mathrm{g} / \mathrm{mL}$

II] $6.25 \mu \mathrm{g} / \mathrm{mL}$ 